\title{
Geographic Embeddedness of Higher Education Institutions in the Migration Policy Domain
}

\author{
Alexandra M. Bozheva \\ Western University, Canada
}

\begin{abstract}
In 2014, Canada issued its first International Education Strategy, articulating targets for international enrollment and its economic benefits, but lacking international student retention goals. Universities and colleges used to be places where students could get immigration advice, but past Bill C-35 only Regulated Canadian Immigration Consultants can provide such advice. There is no requirement for institutions to hire these consultants. I investigate the geographic stretch of the education domain's engagement with retention, through an examination of immigration advising support provision across Canada's campuses. This provision is highly uneven, with a moderate association with school size, reflecting the voluntary nature of such engagement. A defined international student retention strategy could possibly change the current state of immigration governance through the education domain.
\end{abstract}

Keywords: higher education, immigrant retention, international students, RCIC, RISIA

\section{INTRODUCTION}

The priority Canadian universities place on the recruitment of top international talent has converged over the last several years with the government's agenda of attracting these students as a potential pool of high quality immigrants and skilled labour (Association of Universities and Colleges of Canada [AUCC], 2009, p. 4). 
With Canada's 2014 national International Education Strategy (IES), the two domains, education supply and migration management, seem to have reached a unison toward accelerating international student migration to Canada. Yet, I argue, it is the recruitment priorities of education providers that were at the core of the IES, whereas the country's retention goals remained far less defined. Retention of international students was listed as one of the strategic goals: "Increase the number of international students choosing to remain in Canada as permanent residents after graduation" (Department of Foreign Affairs, Trade and Development [DFATD], 2014, p. 17), but the document lacked an elaboration on how to achieve this. From the 14 recommendations of the Advisory Panel on Canada's International Education Strategy (2012), only one spoke to expansion and promotion of the Canadian Experience Class (CEC) as a student retention path. As these recommendations laid the foundation of the IES, it also gave very little space to understanding how international students can potentially transition to permanent residency. This was largely expressed in the following passage:

International students are a future source of skilled labour, as they may be eligible after graduation for permanent residency through immigration programs, such as the Canadian Experience Class (introduced in 2008). International students are well positioned to immigrate to Canada as they have typically obtained Canadian credentials, are proficient in at least one official language and often have relevant Canadian work experience (DFATD, 2014, p. 12).

The lack of a strongly identified national international student retention goal can be attributed to the fragmented and complex nature of Canada's education and migration domains governance. Education is governed at provincial/territorial level, with no federal body in charge (Government of Canada, 1867). Provincial ministries of education collaborate via the Council of Ministers of Education Canada. The migration domain is also fragmented and multilayered, managed by Immigration, Refugees and Citizenship Canada (IRCC) and increasingly by provincial ministries/departments.

Universities are spatially embedded entities, not only within education, but also within the migration domain. Trilokekar and El Masri (2016), examining synergies between the IES and 11 Ontario universities' internationalization strategies, highlighted that much of the variability in the federal-institutional alignment on retention policies depends on institutions' geographical positioning (locally in proximity to major metropolitan areas, and globally in international rankings). Trilokekar and El Masri (2016) concluded that "supporting the transition of international students as new immigrants is a policy arena resulting in close cooperation between the two levels [federal and provincial] of government; however, university strategy documents rarely reflect this policy intent" (p. 554). In the same vein, a study by Covell et al. (2015) discovered that institutions participate in assisting their students in integration on a voluntary basis. Some institutions do have certified services in place, but the overall role of the education community is not clearly defined and remains largely insignificant. With Canada's interprovincial variability in migration policies, we must consider intraprovincial geographic variability 
between institution institutions. Their engagement with retention, under conditions of no established framework for a dialogue between the immigration and education domains, seems to lack any pattern.

This article focuses on the status quo of immigration advising support to international students and questions the state of alignment between the domains involved in international student migration. For policies to be "truly active" there is a need for concordance of agendas, shared vision of outcomes, and coordination of practices (Mosneaga, 2015, p. 16). With this, I ask the following research questions: Is the present Canadian immigration policy approach to international students "truly active? Is there a connection between migration policies and immigration support on Canadian campuses? To answer these questions, this article examines the availability of immigration advising services on Canadian campuses and compares any crossprovincial differences.

Considering geographic embeddedness, I hypothesize that universities located in the peripheral (that is, not Ontario, British Columbia, or Quebec) provinces might be more invested in retention of international students as a part of a broader migration agenda. The provinces, which do not experience large immigration numbers in general and international student migration in particular, might be much more invested in coordinating efforts with universities. In other words, a province's migration agenda could be more pronounced in the actions of the institutions located within it. As a result, universities in such provinces may have a greater extent of international student immigration services.

This article is an analysis of availability of immigration advising services, in universities and colleges throughout Canada, conducted using Immigration Consultants of Canada Regulatory Council (ICCRC) registration information on Regulated Canadian Immigration Consultants (RCICs) and Regulated International Student Immigration Advisers (RISIAs). This analysis is preceded by a discussion of the recent trends in international students transitioning to permanent residents.

\section{ISSUE WITH RETENTION?}

Neoliberal transformations of the education sector in Canada, initiated in the late 1970s, pushed universities to treat international students increasingly not as a source of "diversity on campus" but as a source of a diversified revenue portfolio. Actively advocating for a strategy to "deal with foreign students on a national basis" (AUCC, 1985, p. 9), education institutions collaborated with Global Affairs Canada to institutionalize profit-making internationalization at the federal level, transforming Canada's education services into a well trading export. Canada's first IES became a landmark document, elevating international trade of education from the institutional to the federal level. Being developed in consultation with education institutions, the Council of Ministers of Education Canada, provinces and territories, and other stakeholders, the IES became a proclamation of the national internationalization vision. In it, attraction goals have a clear formulation, while retention goals remain vague. The IES acknowledges the role of immigration in the labor force, anticipates that international students are predisposed for easy integration, yet has no clearly defined retention plans (DFATD, 2014). Such a "retention-lite" approach stands in 
stark contrast to the other objectives: calculated recruitment targets, economic benefits, and investments necessary for education marketing and visitor visa processing, all expressed in concrete dollar amounts.

International students are interested in Canada not only as a location of their education abroad, but as a potential future residence. According to a Canadian Bureau for International Education (CBIE) survey, about half of international students decide on the country first, then on an institution (CBIE, 2009, p. 24). The 2013 survey showed that $60 \%$ had chosen Canada first, and in the 2014 survey, 55.5\% (CBIE, 2014, p. 33). In addition, 59\% consider popular international rankings, such as Times Higher Education, as a factor in their decision (CBIE, 2013, p. 24). Considering international students' future plans in Canada, the 2007 CBIE survey found that $32 \%$ consider staying (Bond et al., 2007, p. 18); later the 2015 survey reported that $51 \%$ of international students consider applying for permanent residency (CBIE, 2015, p. 35). Yet, despite a higher percentage of students willing to stay, IRCC (2019b) data indicates that the number of direct transitions from student to permanent resident declined in 2016 by 34\%, compared to 2006. Lu and Hou (2015, p. 4) estimated the cumulative transition rate (all migration paths included, 10 years since first student permit) for international students being the highest for the early 1990 s cohort, at $27 \%$ becoming permanent residents, with the late 1990 s cohort at $20 \%$, and the early 2000 s cohort catching up at $25 \%$.

$\mathrm{Lu}$ and Hou's (2015) rate is cumulative, meaning that it accommodates all possible migration paths, be those skilled or unskilled work after studies, marriage to a Canadian, or claiming refugee status. Given a spectrum of possible pathways, stagnated retention rates are an outcome, I argue, of a progression toward education commercialization and a fight in the global market. Further, with the pursuit of increasing education as an export and the burgeoning numbers of international students (over 370,000 postsecondary international students in 2017 compared to just over 110,000 in 2007; IRCC, 2017f), the cumulative retention rate could go down from $25 \%$. While Canada plans to increase the overall immigration levels (IRCC, 2017e) and desires to accommodate more international students (Hussen, 2018), it is not clear how international students fit into the outlined brackets, as IRCC "does not currently have targets for the number of international students it would like to transition to permanent resident status but rather sets targets for various permanent residence streams/programs" (Citizenship and Immigration Canada [CIC], 2015, p. 20).

Upon graduation, students are faced with provincial and federal immigration programs, yet they are left to make migration choices with no settlement support services that could help them to navigate these. Temporary residents are not eligible for IRCC-funded settlement services before receiving approval for permanent residency (IRCC, 2018c). Considering that about a half of permanent residency applicants under the Express Entry, uniting the federal economic immigration programs (Federal Skilled Worker, Canadian Experience Class, Federal Skilled Trades), already reside in the country (IRCC, 2018a, p. 13), the current international student retention approach is reactive in nature. Only the Atlantic Immigration Pilot, a new policy formation of the four eastern provinces, has turned to proactive measures providing settlement support, including to international students, at the pre- 
permanent residency-approval stages (IRCC, 2018b). In the rest of the country, "It is absurd to see a very limited social service access for international students since the education and immigration policy proactively recruit them and later absorb them as high skilled labor immigrants into permanent resident status" (Johnstone \& Lee, 2014, p. 217).

Canada's recent international student migration policy history has not been linear. There has been a number of student inflow stimulating measures, including introduction of the Canadian Experience Class in 2008 and creation of a number of provincial nominee programs' (PNPs) streams, designed specifically to retain international students. As these steps were taken forward, they were contradicted by some gatekeeping legislation, such as 2014 "Strengthening Canadian Citizenship Act" that changed the rules for citizenship application by denying students the use their years of temporary residency toward the permanent residency years count (Government of Canada 2014, 10-11). In 2017, the government passed Bill C-6 that counteracted the damages of Bill C-24 (IRCC, 2017c, 2017d), but before that international students had to reconsider their eligibility and future life plans.

Before Bill C-24, another significant barrier came in the form of Bill C-35, or the "Cracking Down on Crooked Consultants Act," in July 2011 (Citizenship and Immigration Canada, 2014, p. iv), limiting student access to immigration advice services and, hence, undermining retention. The measures introduced by the bill are still in effect. The Immigration Consultants of Canada Regulatory Council (ICCRC) became the IRCC designated body regulating Canadian Immigration Consultants (RCICs), and from November 2015 - Regulated International Student Immigration Advisers or RISIAs (ICCRC, 2016, p. 26). The key difference between the two is that RISIAs are limited to providing support on student visas and study permits, whereas RCICs can advise on permanent residency application. There is no regulation requiring education institutions to hire consultants of either type, regardless of international students' enrollment. It is the intuitions' responsibility to decide whether they invest in immigration support on campus.

This "two steps forward, one step back" legislative trajectory, in combination with neoliberal pressures to pursue attraction, means that little progress has been made in retaining international students in the 21st century. IRCC's latest Evaluation of the International Student Program "found that there is a lack of an effective wholeof-government approach between federal departments regarding international students" (Citizenship and Immigration Canada , 2015, p. vi). This article argues that post-IES, when it comes to retention, such an approach is still lacking. Further, the current approach, with no settlement support available to any temporary residents and international students being faced with an array of PNPs' streams, might be causing more confusion (Alboim, 2011; Bond et al., 2007) than facilitating a streamlined retention.

There is still a limited understanding of how universities fit into any province's retention plan. Walton-Roberts (2011) posed the question: With the shift from "red card to the red carpet" in migration policies, "How the higher education sector will manage this responsibility"? (p. 471). Indeed, in Canada today, do universities identify themselves as key facilitators in international student integration, or do they draw their responsibility line at "attraction" with no mandate to be involved in 
"retention"? In other words, does the "red carpet" start with universities? This article contributes to understanding Canada's migration management framework through examining universities as places of talent retention. It identifies which universities go beyond the mandate to educate, and answers whether there is a connection to the international student migration priorities of the province/territory in which such universities are located.

Universities can act as the key facilitators in the transition of international students from temporary to permanent immigrant status. Though many institutions provide services to international students, these are limited in staff and capacities (Covell et al., 2015; El Masri et al., 2015). At the turn of the century, CBIE (2002) noted that "campuses are not adding essential ISA [international student advisors] in line with burgeoning enrolments" (p. 7). As we navigate 2020 and beyond, it is worth exploring if universities, especially after Bill C-35, consider themselves channels of international students retention by providing the necessary RCIC staff.

\section{STUDY FRAMEWORK}

Mosneaga (2015) suggested that when it comes to international students, the concept of "migration management" - a policy term referring to a totality of migration policies exercised by nation-states - should be extended to lower domains, where international students come into contact with educational and labor market infrastructures. Walton-Roberts (2011) added that in knowledge economies, with skills-oriented migration systems, universities are to become increasingly central to "channeling and driving immigration" (p. 455). Adopting these approaches, I examine Canada's migration management framework, extending it to an education institution level. Figure 1 reflects such an understanding of Canada's international student migration management framework, incorporating national and provincial level actors from the two domains: migration regime and education supply.

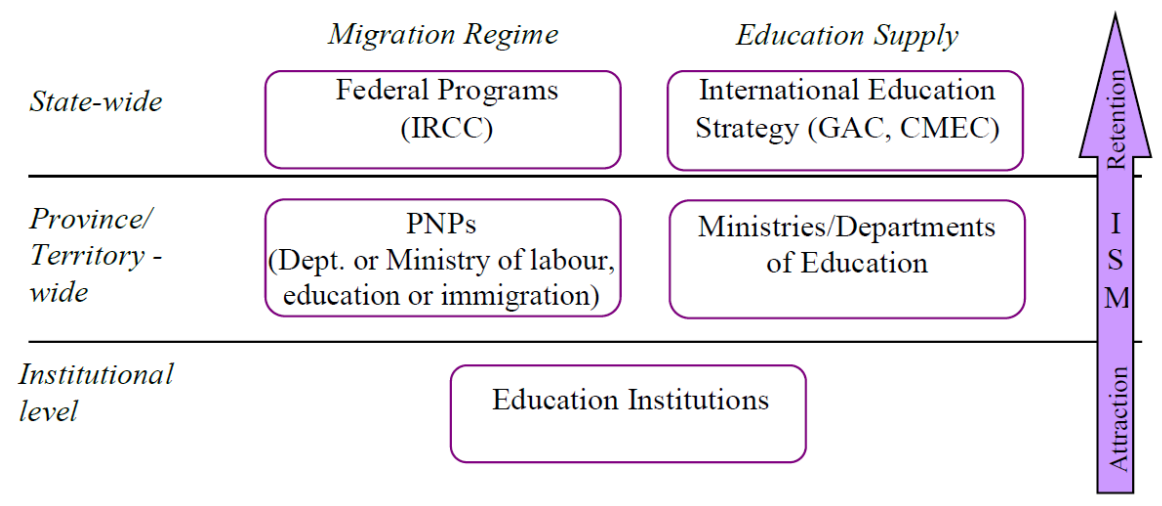

\section{Figure 1: Canada's International Student Migration Management Framework}

This framework could include other stakeholders, such as employers or regulated professions associations (see Covell et al. 2015), but the focus of this article is on the 
tangency points between education and immigration domains. This article highlights the role of higher education institutions in international student retention. According to postsecondary education enrollment data, $70 \%$ of postsecondary international students are studying in the top three cycles of university education: bachelor's, master's, and PhD programs (Statistics Canada, n.d.), making universities and colleges key stakeholders in drawing a "potential pool of high quality immigrants" (AUCC, 2009, p. 4) into the country.

\section{METHOD}

First, I review IRCC data on international students transitioning to permanent residency. The necessary dataset was obtained through Canada's Open Government Portal. I use these data to calculate the proportion of international students transitioning to permanent residency through PNP for each province. This is essential information not only for understanding the paths that students choose, but for understanding which programs might be more efficient in retention, provincial or federal.

I then present findings from an analysis of the availability of international student immigration advising services, based on the ICCRC registration information. The focus of this article is on universities and colleges, or diploma- and degree-granting institutions. These institutions not only enroll $70 \%$ of long-term international students in the country (Statistics Canada, n.d.), top-level graduates are also actively targeted by provincial programs (Bozheva, 2020). ICCRC maintains a registry of RCICs and RISIAs on its website (ICCRC, n.d.). The list of the currently accredited RISIAs is available and updated often. This article uses the list dated July 3, 2018, containing 111 specialists. Information on availability of RCICs was retrieved on July 25, 2018, using a keyword search in the ICCRC registry based on the "Company name field," which is institution name. Institutions' names were entered with variants to minimize the discovery error. For example, the University of British Columbia was also entered as UBC. The search revealed that there are consultants providing advice for several institutions simultaneously, meaning some institutions are served remotely. Such shared consultants were counted for each institution they serve.

The list of degree-granting institutions was created based on the Canadian Information Centre for International Credentials (CICIC), which is a part of the Council of Ministers of Education Canada directory (CICIC, n.d.). Only recognized and authorized public and private universities and colleges (not private career colleges and vocational/technical schools) that have been approved as designated learning institutions for Canada's international student program were included in the analysis. For Quebec, due to the specificity of its education system, only universities were included in the analysis, colleges and cegeps (Collège d'enseignement général et professionnel) were excluded. The final list included 202 institutions, 117 universities and university colleges, and 85 colleges.

After these data were collected, immigration services provision levels were calculated as the percentage of institutions with at least one RCIC to the total number of select institutions in a province. Further, the number of available RCICs on Canadian campuses was compared against international students' enrollment in the 
top three cycles of postsecondary education (Statistics Canada, The Postsecondary Student Information System), by calculating the RCIC availability per 1,000 international students index.

In addition, for an examination of whether RCICs' availability depends on enrollment body size, independent sample $t$ test and bivariate correlations were performed. The enrollment data for 2016 was obtained from Universities Canada, collecting statistics on its members. Enrollment data for 93 Universities Canada members were available. To estimate the size of the international student body, I used the information on the percentage of international students in first-year undergraduate and overall graduate enrollment, collected by Maclean's Magazine from the participating institutions (Dwyer, 2017; Maclean's, 2017, p. 83). Maclean's reported the presence of graduate international students for Medical Doctoral and Comprehensive universities only, based on their broader graduate programs' offerings. This limits the analysis to universities only, affecting the sample size; nevertheless, it is telling.

The uneven participation of the institutional domain in international student migration needs to be considered within the geographical context of international enrollment and international students transitioning to permanent residency. The calculated provincial shares in the distribution of postsecondary international students and the rates of international students transitioning to permanent residency through PNPs were plotted on a map against the estimated RCIC and RISIA provision rates. The resulting map served as a base for a comparative analysis of the institutional domain's engagement with international student retention.

\section{International Student Transitions to Permanent Residency}

Immigrant countries of origin are often thought of and pictured in statistics as countries of birth or citizenship, not as countries of actual residence. However, Express Entry data showed that in 2015, 78\% of invited candidates resided in Canada (IRCC, 2017b, p. 14); in 2016, 64\%; in 2017, 49\%; and in 2018, 45\% (IRCC, 2018a, p. 13; 2019a, p.12). This effectively means that, while the electronic system makes permanent residency application process more accessible for applicants from outside of Canada, the country continues to be the main immigrant source country to itself, with temporary workers and international students being the key ingredients in the make-up of immigration. Express Entry includes federal economic programs, but many provinces operate streams that are not integrated with the system. The observed decrease of Canadian applicants in Express Entry seem to be compensated by PNPs, as the overall role of PNPs in transitioning of temporary to permanent residency has increased. The proportion of temporary residence-principal applicants under PNPs between 2010 and 2015 grew to 76\%, with the highest numbers in Northwest Territories (98\%), British Columbia (96\%), Yukon (94\%), Ontario (93\%), Newfoundland and Labrador (88\%), Alberta (84\%), Nova Scotia (75\%), and Saskatchewan (61\%), versus New Brunswick (40\%), Manitoba (23\%), and Prince Edward Island (20\%) (IRCC, 2017a, pp. 19-20). Quebec plans "to increase to at least $40 \%$ in 2019 the proportion of immigrants ... of the subcategory of skilled workers, selected and having either a temporary worker or a foreign student status in Quebec 
at the time of their selection" (Ministère de l'Immigration, de la Diversité et de l'Inclusion, 2016, p. 8). ${ }^{1}$

IRCC's evaluation of the international students program indicated that in 20092013 in transitioning to permanent residency the PNPs' share has been increasing, and substantially ahead of CEC, and opposite to dropping numbers under the FSW category (Citizenship and Immigration Canada, 2015, p. 19). The most recent IRCC transitions data reveal that popularity, or, one can say, "efficiency of different paths" depends on the previously held status, and that PNPs have been losing their appeal for international students. Table 1 examines admissions to permanent residency from prior study permit or postgraduate work permit (PGWP) holder status, which I consider to be the two main statuses international student/potential immigrants can have, being temporarily in Canada. Note that for studies under 6 months, a study permit is not required (IRCC, n.d.), making such international students ineligible for PGWP and for permanent residency under most streams (Bozheva, 2020).

Table 1: Transition Paths of International Students to Permanent Residency from Study Permit and Postgraduation Work Permit Statuses, \%.

\begin{tabular}{lccccc}
\hline Transition paths & 2015 & 2016 & 2017 & 2018 & $\begin{array}{c}2019 \\
\text { (Q1-2) }\end{array}$ \\
& & & & & \\
\hline From SP to PR paths & & & & 0.8 & 3.2 \\
$\quad$ Atlantic Pilot & 25.4 & 25.3 & 24.9 & 30.6 & 29.2 \\
$\quad$ PNPs & 18.4 & 20.5 & 17.7 & 18.7 & 12.2 \\
$\quad$ Quebec & 56.1 & 54.2 & 57.4 & 49.9 & 55.4 \\
$\quad$ Federal programs & 45.5 & 42.9 & 33.4 & 30.9 & 29.2 \\
Total in IS to PR transitions & & & & & \\
From PGWP to PR paths & & & 0.1 & 0.7 & 1.8 \\
$\quad$ Atlantic Pilot & 43.8 & 33.9 & 25.6 & 31.0 & 35.0 \\
$\quad$ PNPs & 20.6 & 22.4 & 16.3 & 14.4 & 5.5 \\
$\quad$ Quebec & 35.5 & 43.7 & 58.1 & 53.9 & 57.7 \\
$\quad$ Federal programs & 54.5 & 57.1 & 66.6 & 69.1 & 70.8 \\
Total in IS to PR transitions & 100 & 100 & 100 & 100 & 100 \\
Total IS (SP+PGWP) to PR by path & & & 0.1 & 0.8 & 2.2 \\
$\quad$ Atlantic Pilot & 35.4 & 30.2 & 25.4 & 30.9 & 33.3 \\
$\quad$ PNPs & 19.6 & 21.6 & 16.8 & 15.7 & 7.4 \\
$\quad$ Quebec & 45.0 & 48.2 & 57.8 & 52.6 & 57.1 \\
$\quad$ Federal programs & 18,760 & 19,230 & 28,140 & 35,480 & 14.310 \\
Total IS (SP+PGWP) to PR (in & & & & & \\
absolute numbers) & 100 & 100 & 100 & 100 & 100 \\
Transitions from TR to PR & 27.6 & 31.6 & 36.2 & 38.6 & 39.0 \\
IS (SP+PGWP) & 59.1 & 57.0 & 56.2 & 56.3 & 55.4 \\
IMP (non-LMIA) & 13.2 & 11.4 & 7.5 & 5.1 & 5.5 \\
TFW (LMIA) & & & & &
\end{tabular}

${ }^{1}$ Google Translate. 
Transitions from TR to PR (in

absolute numbers)

Note. $\mathrm{SP}=$ study permit; $\mathrm{PR}=$ permanent residency; $\mathrm{PNP}=$ provincial nominee programs; IS = international student; PGWP = post-graduation work permit; LMIA $=$ Labour Market Impact Assessment; TR = temporary resident; IMP = International Mobility Program; TFW = Temporary Foreign Worker. Data source: IRCC, 2019b, 2019c, 2019d, and 2019e. Federal programs include sponsored family members.

Overall, there has been a growing number of students obtaining permanent residency, which has impacted the overall number of the temporary residents transitioning to permanent residency. There are four statuses, under which temporary residence can be present in the country: the already mentioned study permit and PGWP for international students, and temporary work permit obtained either through International Mobility Program (IMP) that does not require a Labor Market Impact Assessment (LMIA) or through Temporary Foreign Worker (TFW) program requiring an LMIA. The Table 1 data indicates that while temporary workers dominate transitions to permanent residency, their cumulative share (IMP+TFW) have dropped in the recent years from $72 \%$ to $61 \%$ (mostly due to declining TFW share), with international students becoming a growing source of immigrants to Canada, representing almost $40 \%$ of temporary-to-permanent residency transitions.

Significantly, direct transitions from study permit-to-permanent residency have declined and students transition increasingly after getting post-graduation work experience $(69.1 \%$ in 2018). This is caused by the growing profit-making under the IES, causing a rejuvenation of international student inflow through an increased presence of undergraduate student programs (Statistics Canada, n.d.). With younger students without work experience, direct transitions from study permit to permanent residency might decline further. Among study permit holders, the distribution between pathways to permanent residency have been more or less stable in the last years, with $25 \%$ going through PNPs, under $20 \%$ admitted through streams in Quebec, and slightly over 55\% choosing federal paths. The most recent data reveal that PNPs rewarding international students experience might be gaining a momentum.

For PGWP holders, the situation has been changing dramatically. PGWP holders increasingly opt for federal programs (up to $58.1 \%$ in 2017), finding PNPs, with many designed with post-graduation working experience in mind (Bozheva, 2020), less suitable. Though PNPs' contribution seems to be on a rise lately, federal programs are still dominating pathways to permanent residency. What these data reveal about international student migration cannot be overestimated. Once having obtained Canadian experience on PGWP, students choose not to be geographically bounded by a province, choosing to apply through a federal program. The push for PWGP by the CEC requirements and by the majority of employer-based PNPs makes getting one a necessary pre-immigration step. Once it is accomplished, international students prefer standard federal programs over a plethora of PNPs, causing this path to gain strength over the years, with $57.8 \%$ of the total transitions to permanent residency from the two statuses in 2017, and $57.1 \%$ in the first two quarters of 2019. On the other hand, this could be caused by the PNPs' thresholds: Each province can nominate 
only a certain number of applicants, negotiated with IRCC (IRCC, 2017e). Not all PNPs specify on their websites how many students they are willing to accept; it is hard to judge what is the total allocation for students under all of the PNPs. However, due to the increase in the overall number of international student transitions, particularly between 2016 and 2017, combined with the predefined overall PNPs' limits, we could be witnessing a natural increase in the use of the federal programs. Yet, the growth in permanent residency admissions between 2015 and 2016 was not that significant, only $2.5 \%$, but the drop in the PGWP-holders channeled through PNPs was almost 10 percentage points. Thus, there could be a double jeopardy for PNPs when it comes to students on PGWP: declining attractivity complicated by the programs' caps. Considering that in November 2016 Express Entry was adjusted to reward international students with extra points for Canadian credentials (IRCC, 2017b, p. 5), it is probable that the role of PNPs in international student migration, at least for the PGWP-holders component, could further decline.

The emergence of the supraregional Atlantic Immigration Pilot, driven by shared demographic and immigrant retention concerns, aimed to achieve "the immigration lifecycle of recruitment, processing, settlement and retention, [taken] into consideration when implementing immigration policy" (Standing Committee on Citizenship and Immigration, 2017, p. 30). Further, the Atlantic provinces expressed that "few students are aware of their eligibility for the specific stream designed for international graduates," asking IRCC to "allow international students...to access settlement services once they have started the permanent residency application process" (pp. 34, 39). Since March 2017, international students have access to settlement services as a part of the permanent residency application process under the Atlantic International Graduate Program. Outside of the region, settlement support for international students is practically absent. The matters of immigration advice and support are handled by education institutions on a voluntary basis. While having RISIAs might be considered a necessary means to guarantee a smooth international enrollment process, hiring RCICs is indicative of institutions' willingness to partake in a province- and nation-wide talent retention agenda.

\section{Availability of Immigration Consultants on Canadian Campuses}

According to ICCRC's 2017 report, there are 4,121 RCICs working in Canada and 163 elsewhere abroad (ICCRC, 2017, p. 7). Based on the registry scan, only 98 RCICs work on campuses of the 202 considered institutions, representing less than $2.5 \%$ of the in-country specialists. Universities are more likely to employ an immigration consultant, with 74 RCICs working at universities versus 24 at colleges. Similarly, a majority of RISIAs are employed by universities, with 60 out of the 102 registered advisers working at universities, and 42 at colleges (Quebec's excluded).

Availability of immigration help is not even across the 202 institutions and across provinces. The national level of the immigration advising provision, estimated as the percentage of schools offering the designated specialists, is shown in Table 2. Colleges and universities are hiring RISIAs at a similar rate, and fewer than $30 \%$ of them have advisers on campuses. When it comes to RCICs, hiring immigration consultants is a more widespread practice among universities than colleges. Overall, 
the provision of specialists eligible to help with application to permanent residency is low: $26 \%$ of 117 universities offer such support, and only $21 \%$ of 85 colleges. Out of 48 institutions with RCICs, 30 schools also have RISIAs, meaning that availability of both kinds of specialists is limited to a small number of schools).

Table 2: National Provision Levels of Regulated International Student Immigration Advisers (RISIAs) and Regulated Canadian Immigration Consultants (RCICs)

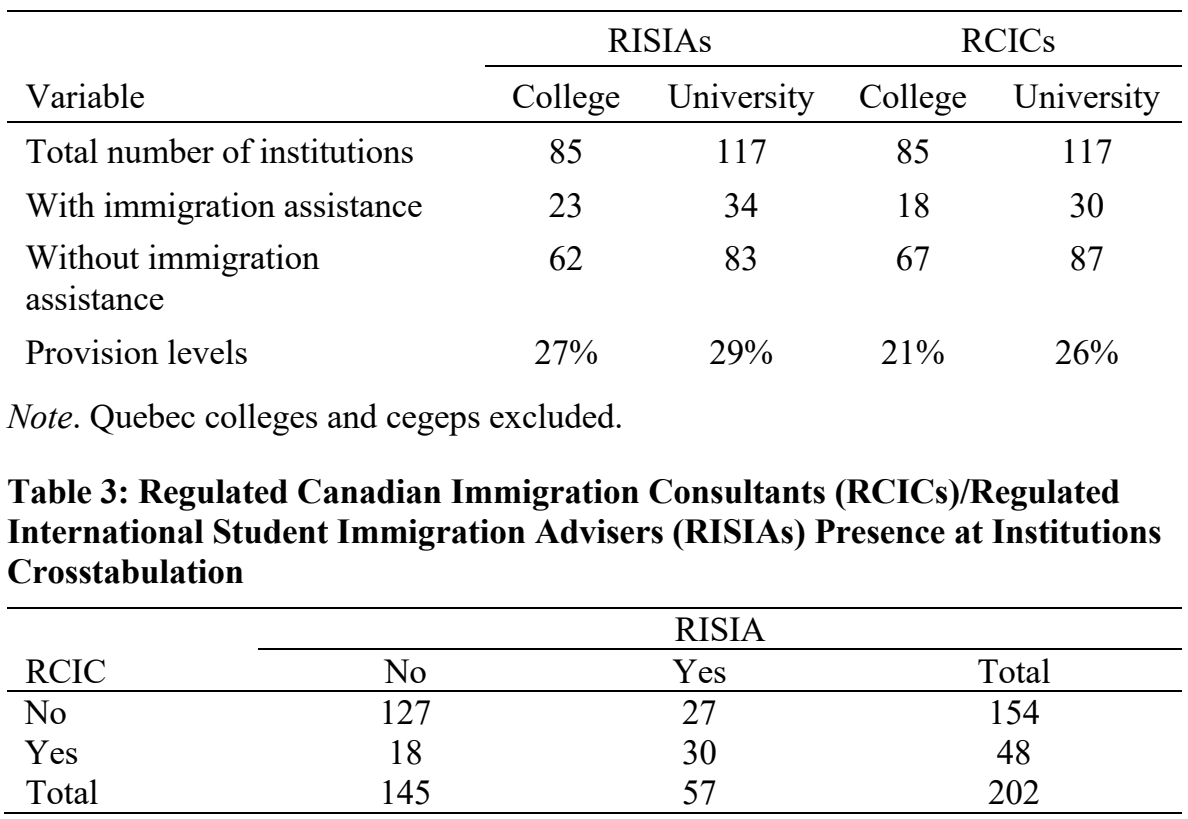

Availability of immigration consulting staff may depend on institutional resources. Statistical testing indicated that RCICs are likely to be found in schools with substantial total enrollment numbers, including undergraduate and graduate components (Pearson's $R=.600^{* *}, .608^{* *}, .506^{* *}$, respectively, $n=29$ ). ${ }^{2}$ When considering the size of the international student body, schools hiring RCICs tend to have a greater international student presence in the undergraduate first-year enrollment in terms of the proportion and absolute numbers. Examining the Maclean's list of comprehensive and medical doctoral schools, which includes 29 of the top 30 largest universities in the country (excluding Athabasca University, as its primary delivery mode is distance studies), reveals that the graduate international student body size does not vary significantly between schools with and without RCICs $\left(t=0.802, d f=28, N_{1}=18, N_{2}=12\right.$; and $\left.R=.290, p=.242, N=18\right)$. The undergraduate international student body for these institutions differs between universities with and without RCICs, but with under a 95\% level of statistical

${ }^{2}$ Full statistical output is available upon request. 
significance. This indicates that though size of student body is connected to RCICs' availability, many of the largest universities do not employ immigration consultants, despite having a significant international student enrollment. Concordia University and Western University are similar in size of the total and international undergraduate enrollment, yet the former has zero RCICs, while the latter has five.

There is a highly uneven distribution of the employed RCICs between institutions and between provinces. Out of the 98 RCICs working in 48 degree granting institutions (out of the 202 considered), 52 work in 10 of them (Table 4). Most of RCICs are working for institutions in British Columbia, Ontario, and Alberta. The Atlantic provinces collectively share 10 RCICs. The region recently has moved toward a shared policy space, meaning that students may now access necessary immigration consulting outside of campus.

Table 4: Leading Institutions in Regulated Canadian Immigration Consultants (RCICs) Provision, as of July 25, 2018

\begin{tabular}{llll}
\hline Institution & Province & City & RCICs \\
\hline The University of British Columbia & BC & Vancouver & 10 \\
University of Waterloo & ON & Waterloo & 6 \\
University of Alberta & AB & Edmonton & 6 \\
University of Toronto & ON & Toronto & 5 \\
York University & ON & Toronto & 5 \\
Simon Fraser University & BC & Burnaby & 5 \\
Western University & ON & London & 5 \\
Dalhousie University & NS & Halifax & 4 \\
University of Calgary & AB & Calgary & 3 \\
University of Victoria & BC & Victoria & 3 \\
\hline
\end{tabular}

The uneven participation of institutions in international student migration needs to be considered within the geographical context of international student enrollment and international students transitioning to permanent residency. The map in Figure 2 incorporates such a context with the availability of RCICs and RISIAs. It offers estimates of RCICs' availability per 1,000 international students enrolled in the top three cycles of higher education (bachelor's, master's, and $\mathrm{PhD}$ or equivalent programs). Use of a standardized measure accommodates for interprovincial differences in the scale of international student enrollment.

International student enrollment in the top cycles is led by three provinces: Ontario (36.3\%), Quebec (22\%), and British Columbia (20.5\%), followed by Alberta $(7 \%)$. The very same provinces are the top destinations for the students transitioning to permanent residency, albeit with Ontario and Alberta being even more attractive as settlement destinations versus study destinations. There is an important caveat: The direct comparison between the two indicators is not possible as there are no publicly 
available data on transitions by level of education. In the east, Nova Scotia is the indisputable leader. Together with Manitoba and Saskatchewan, it forms a secondtier league in international student migration.

There is a pattern in the provinces' reliance on PNPs in international student-topermanent resident transitioning. The lower a province's share in the total international student enrollment and the number of international students destined to the province, the higher the share of international students obtaining permanent residency via PNP. This trend is true with two exceptions. Quebec does not have a PNP, making it incomparable directly with the rest of the provinces. New Brunswick, Newfoundland, and Labrador are another exception. Along with Ontario and British Columbia, these two jurisdictions have lower levels than could have been expected by their PNPs' utilization by international students, distinguishing them from other peripheral provinces.

Ontario and British Columbia PNPs offer streams for certain groups of students, such as master's and PhDs, not requiring a labor market attachment through a job offer or work experience (Bozheva, 2020). Considering this, one could expect a higher proportion of international students transitioning via PNPs there. I could hypothesize that based on the overall provincial nomination limits for British Columbia $(6,250)$ and for Ontario $(6,600$, allotment for 2018) (British Columbia Provincial Nominee Program, n.d.; Ontario Citizenship and Immigration, 2018) and significant international student enrollment levels, there could be a "spillover" effect. When a PNP's capacity is not able to absorb all applicants, redirection to federal streams is inevitable. If the caps are filled with top level graduates, then the rest of international students, willing to stay in British Columbia or Ontario, would have to apply through federal streams.

Lower PNPs utilization in New Brunswick and Newfoundland and Labrador are surprising, as the other two provinces in the region seem to rely heavier on their programs. The situation with PNPs in the region is mostly likely to change soon. With extension of the Atlantic Immigration Pilot, other individual provincial programs are likely to be negotiated with the IRCC.

The leading four provinces employ more RCICs compared to the rest of Canada. However, considering that they host a majority of universities and colleges, this advantage disappears, particularly within universities. The Atlantic provinces' proportion of universities offering RCICs' services is comparable to the leading provinces'. In Prince Edward Island, the main of two universities, the University of Prince Edward Island, employs RCICs. Maritime Christian College is largely a theological school with a smaller enrollment. Factoring this in, by the virtue of a lesser number of institutions, Prince Edward Island has the highest provision of immigration support across its universities. In Manitoba, two out of two colleges employ RCICs, bringing the provision level for this type of institution to $100 \%$. Manitoba universities do not participate in retention to the same extent; their RCICs provision is among the lowest in the country. Saskatchewan presents a special case, comparable to Manitoba by size of international student enrollment and international students' admission to permanent residency, but not offering immigration consulting in any of its colleges or universities (as of July 25, 2018). 
With varying RCIC provision levels, we can observe the extent of geographical spread of immigration support. In addition, it is important to estimate a standardized measure accounting for both: the number of specialists working and the number of international students in a province. This allows estimation of specialists' accessibility - in other words, potential client load per RCIC staff member. Focusing on the bachelor's and higher (bachelor+) levels of international student enrollment, I calculated the number of RCICs employed on campuses per 1,000 international students in each province. Saskatchewan employs zero RCICs and has zero availability, but Quebec is not far off from this level with 0.06 RCICs available. This study did not include Quebec colleges; hence this index might be improved with inclusion of such institutions. However, my earlier preliminary scan of the ICCRC registry, on October 31, 2017, revealed that out of 172 CICIC-identified designated learning institution colleges in Quebec, only Institut Teccart had RCICs, employing two. Institut Teccart still has two RCICs, bringing the index of availability per 1,000 international students to 0.12 - still substantially below Ontario and British Columbia.

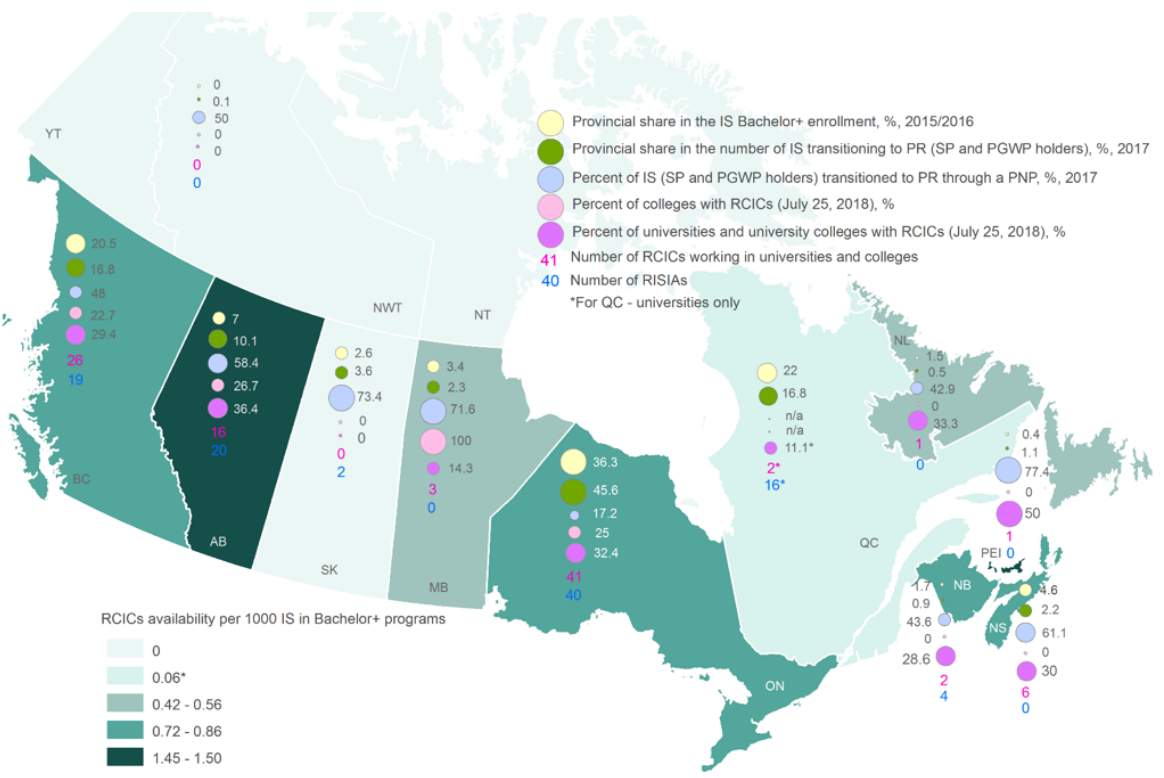

Figure 2: International Student Migration and Provision of Immigration Support on Canadian Campuses. (Statistics Canada n.d., 477-0019; IRCC 2019b,c; the Author's scan of the ICCRC registry).

Manitoba and Newfoundland and Labrador offer around 0.5 RCICs available per 1,000 for bachelor+ international students. Ontario and British Columbia do not employ enough RCICs for the enrollment of their size. They are in one group with Nova Scotia and New Brunswick, with RCICs' availability varying between 0.7 and 0.9. The leading provider of immigration support on campuses is Alberta. The 
province has favorable numbers in the "spread" of immigration support, especially across universities, and in terms of RCIC availability at 1.45 specialist per 1,000 bachelor+ students. Prince Edward Island has only one RCIC registered, but due to the province's lower enrollment (under 700 international students studying in bachelor+ programs), the availability is higher than in the rest of Canada, at 1.49 per 1,000 international students. Collectively, the Atlantic provinces have RCIC staff availability at 0.78 , which brings the region on par with British Columbia and Ontario.

I hypothesized that universities located outside of the top three provinces might be more invested in student retention as part of a wider provincial skilled immigration agenda. This intuitive assumption was mostly confirmed by the estimated immigration consultant provision and standardized (per 1,000) RCIC availability levels. Though the "core" provinces host most of the largest universities and colleges and have more resources to provide support to their international students, the currently available support is not adequate to their international enrollment size. Popularity of these provinces is unlikely to decline, and one might think that those provinces and institutions adopt a laissez-faire approach to retention. However, Ontario and British Columbia keep advancing their PNPs (Bozheva, 2020) and the top schools employ RCICs in numbers (Table 4). To the disadvantage of international students, the pace of enrollment outpaces immigration support spread and availability.

Yet, Ontario and British Columbia are still ahead of many provinces: Saskatchewan, Manitoba, Newfoundland, and Labrador. Quebec, separate from the rest of the country's immigration policy space, still would benefit from providing more support, as it plans to increase immigration intake from temporary workers and students (Ministère de l'Immigration, de la Diversité et de l'Inclusion, 2016, p. 8). All of Canada needs to provide a more consistent management of international student migration, with higher RCIC staff availability across campuses, as even the highest observed level was only 1.5 immigration consultant per 1,000 international students.

\section{DISCUSSION AND CONCLUSIONS}

In the post Bill C-35 era, universities and colleges are getting involved in migration, yet at different speeds. The interest in hosting international students, confirmed by the greater geographical spread of RISIA provisions across both types of institutions, prevails. Offering transition to permanent residency support is a less widespread practice, with under $25 \%$ of the considered institutions having RCIC staff available. RCICs' presence and their number on campuses are connected to institution's size and administrative capacity. Yet, the association between the two variables is moderate, as some schools are underhiring RCICs, relative to their enrollment size. Simon Fraser University has a total enrollment of close to 30,000 and the estimated international student body 5,700+; the University of Toronto has total enrollment 3 times larger, with international student body close to 21,500 (Maclean's, 2017; Universities Canada, 2016); however, both have the same number of RCICs-five. Such disproportion in RCIC availability extends from the interinstitutional to 
interprovincial level. The leading provinces (Ontario, British Columbia, and Quebec) are not leading the way in providing immigration support adequate to their enrollment. Alberta and Prince Edward Island, two peripheral provinces, supply more RCICs for their international students.

It is encouraging to observe the big players in international student attraction, individual institutional and regional, stepping up in their involvement in permanent student stay, yet, the unevenness of the geography and depth of support (RCICs per 1,000 international students) demonstrates a pattern reflective of a poorly managed retention strategy. All 10 provinces have PNP streams designed for international students, and it is difficult to argue that they are unwanted by Canada. What is lacking are proactive coordinated collaborations of the two domains: migration policymaking (at provincial and federal levels) and education institutions, such as those being put in practice in the Atlantic region.

The first IES came into realization with the federal government obtaining clear economic estimates, provided in the reports commissioned by Global Affairs Canada (see Roslyn Kunin \& Associates, 2009, 2012, 2016). The institutional and governmental domains arrived at the junction of financial benefits, and the trade part of international student migration became well-articulated in the IES. Considering international student retention, there is no national strategy shared between the two domains. Why? By the government's own admission, Canada does not have the same economic clarity on permanent settlement of students versus utilizing them as global ambassadors in the education market or connectors enhancing the country's international presence in other spheres:

The Government of Canada recognizes the benefits both to having international students stay on in Canada permanently after their studies, as well as return home. ...neither CIC nor DFATD [now Global Affairs Canada] have attempted to quantify the relative benefits gained when an international student decides to stay or decides to return home...

In light of this, there may be a need to further examine the relative benefits of international students working and transitioning versus international students returning to their home country; and, review the policy alignment between the ISP [international student program] and CIC's [now IRCC] other temporary and permanent resident programs as well as DFATD's objectives under the International Education Strategy (Citizenship and Immigration Canada, 2015, pp. 20-21).

This excerpt is revealing of the current state of affairs between international student migration stakeholders. Canadian federal government, provinces, and education institutions have agreed to increase enrollment "to more than 450,000 by 2022" (DFATD, 2014, p. 11), but they have yet to agree on how many should stay. Until quantifiable benefits from retaining international students in Canada are produced, we might not see the Atlantic provinces' take on migration approach spreading nationwide.

The geographies of immigration for studies and international student permanent settlement are two layers that may never align. Cities and provinces, hosting top 
universities and most international students, might be more selective in choosing who stays, or have a lesser capacity to transition international students to permanent residency at the same scale as their enrollment (two possibilities are not mutually exclusive). And, peripheral provinces, under-receiving immigrants, might be more interested in absorbing international students as permanent residents. Ontario hosts $36 \%$ of degree-education students and receives $45 \%$ of settling permanently in the country, with only $17 \%$ of them transitioning through Ontario's PNP (Figure 2). These numbers indicate simultaneously three possibilities: Ontario's PNP's limited capacity, its questionable efficiency over the federal programs, and that a substantial proportion of the retained-in-Ontario international students did not study in the province. In other words, there is a channeling of international students away from the provinces that might need them more. All three concerns require attention. The Atlantic International Graduate program is an attempt to merge the two geographies and retain international students within the region of studies.

For an effective permanent retention nationwide, the federal and provincial governments and education stakeholders need to decide on how the two geographies are to adjoin and at what scale. This would entail strategic rethinking of provincial nominee and federal streams, with the goal of a more harmonized distribution of international students, which does not imply a simple equalizing "leveling off" in retention. Inevitably, geographic variability in education location-related factors (global reputation, availability and quality of programs, tuition fees) has an impact on distribution of international students. Nor less important and far less directly manageable are the factors associated with the socioeconomic environment of institution location (wage levels, career opportunities), with which a certain geographic disparity between international student location at education and international student location at immigration is expected. However, migration policy tools and pre-permanent residency transition support services, as demonstrated by the Atlantic Pilot, can be used to coordinate student attraction and retention more effectively for the benefit of all stakeholders.

In this managed international student retention, universities could become a network of immigration supporting agents, where the necessary staff (RCICs) are made available. A coordinated international student retention strategy, involving all the layers of international student migration governance (Figure 1) would elevate Canada's international student migration policy to "truly active."

\section{ACKNOWLEDGMENTS}

My endless gratitude extends to my supervisor, Dr. Belinda Dodson. The time and input she has given me are simply invaluable. I also thank the anonymous reviewers for the comments on the earlier draft of this article. 


\section{REFERENCES}

Advisory Panel on Canada's International Education Strategy. (2012). International education: A key driver of Canada's future prosperity, final report (p. 98). Foreign Affairs and International Trade Canada. https://www.international.gc.ca/education/assets/pdfs/ies_report_rapport_seieng.pdf

Alboim, N. (2011). From international student to permanent resident: Policy considerations. Canadian Diversity, 8(5), 15-19.

Association of Universities and Colleges of Canada. (1985, November). The universities and Canada's international relations. A brief to the Special Joint Committee on Canada's International Relations.

Association of Universities and Colleges of Canada. (2009, August 14). Universities matter: How Canada's universities contribute to economic recovery and longterm prosperity. Pre-budget submission to the House of Commons Standing Committee on Finance.

Bozheva, A. M. (2020). Canada's international student migration policies landscape. Manuscript submitted for publication.

British Columbia Provincial Nominee Program. (n.d.). Invitations to apply. Retrieved July 10，2018， from https://www.welcomebc.ca/Immigrate-to-B-C/B-CProvincial-Nominee-Program/BC-PNP-Tech-Pilot

Bond, S., Areepattamannil, S., Brathwaite-Sturgeon, G., Hayle, E., \& Malekan, M. (2007). Northern lights: International graduates of Canadian institutions and the national workforce (p. 58). CBIE.

The Canadian Bureau for International Education. (2002). National report on international students in Canada 2000/2001.

The Canadian Bureau for International Education. (2009). Canada first: The 2009 survey of international students (p. 88).

The Canadian Bureau for International Education. (2013). A world of learning 2013: Canada's performance and potential in international education (p. 84).

The Canadian Bureau for International Education. (2014). A world of learning 2014: Canada's performance and potential in international education (p. 74).

The Canadian Bureau for International Education. (2015). A world of learning 2015: Canada's performance and potential in international education (p. 64).

Citizenship and Immigration Canada. (2014). Evaluation of the Immigration Consultants of Canada Regulatory Council (p. 61).

Citizenship and Immigration Canada. (2015). Evaluation of the International Student Program (p. 66).

Canadian Information Centre for International Credentials. (n.d.). Directory of educational institutions in Canada. Retrieved December 4, 2017, from https://www.cicic.ca/868/Search-the-Directory-of-Educational-Institutions-inCanada/index.canada

Covell, C. L., Neiterman, E., Atanackovic, J., Owusu, Y., \& Bourgeault, I. L. (2015). Study-migration pathway: Understanding the factors that influence the employment and retention of international students as regulated health 
professionals in Canada (p. 66). http://p2pcanada.ca/wpcontent/blogs.dir/1/files/2015/12/Study-Migration-Pathway.pdf

Department of Foreign Affairs, Trade and Development. (2014). Canada's international education strategy: Harnessing our knowledge advantage to drive innovation and prosperity. Queen's Printer.

Dwyer, M. (2017, November 27). These Canadian universities have the most international students: How schools compare for welcoming out-of-province and foreign students. Maclean's Magazine. https:/www.macleans.ca/education/which-canadian-universities-have-themost-international-students/

El Masri, A., Litchmore, R., \& Choubak, M. (2015). The global competition for international students as future immigrants: The role of Ontario universities in translating government policy into institutional practice. Higher Education Quality Council of Ontario.

Government of Canada. (1867). Canada's Constitution Act. Section 93: Education. http://laws-lois.justice.gc.ca/eng/Const/index.html

Government of Canada. (2014). An Act to Amend the Citizenship Act and to Make Consequential Amendments to Other Acts (Bill-C-24). S.C.2014, C.22. The Speaker of the House of Commons. http://loislaws.justice.gc.ca/eng/AnnualStatutes/2014 22/page-1.html.

Hussen, A. (2018). Canada's 2018 immigration levels plan, Standing Committee on Citizenship and

Immigration. http://www.ourcommons.ca/DocumentViewer/en/42-1/CIMM/meeting97/evidence

Immigration Consultants of Canada Regulatory Council. (n.d.). The council's registry. Retrieved January 12, 2018, from https://iccrc-crcic.ca/find-aprofessional-frame/

Immigration Consultants of Canada Regulatory Council. (2016). Annual report 2015-2016. (p. 33).

Immigration Consultants of Canada Regulatory Council. (2017). 2017 Annual Report: Building a stronger path to enhance consumer protection \& the effective registration of immigration/citizenship services (p. 41). https://iccrccrcic.ca/about-us/publications/annual-reports/

Immigration, Refugees and Citizenship Canada. (n.d.). Get a study permit-Find out if you are eligible to study in Canada. Retrieved July 16, 2018 from https://www.canada.ca/en/immigration-refugees-citizenship/services/studycanada/study-permit/eligibility.html

Immigration, Refugees and Citizenship Canada. (2017a). Evaluation of the provincial nominee program (p. 44).

Immigration, Refugees and Citizenship Canada. (2017b). Express entry year-end report 2016 (p. 22).

https://www.canada.ca/content/dam/ircc/migration/ircc/english/pdf/pub/ee2016-eng.pdf

Immigration, Refugees and Citizenship Canada. (2017c, June 19). BackgrounderBill C-6 receives royal assent. https://www.canada.ca/en/immigration-refugeescitizenship/news/2017/06/bill c-6 receivesroyalassent0.html 
Immigration, Refugees and Citizenship Canada. (2017d, October 10). Backgrounder-Changes to the Citizenship Act as a result of Bill C-6. https://www.canada.ca/en/immigration-refugeescitizenship/news/2017/10/changes to the citizenshipactasaresultofbillc-6.html

Immigration, Refugees and Citizenship Canada. (2017e, November 1). NoticeSupplementary Information 2018-2020 Immigration Levels Plan. https://www.canada.ca/en/immigration-refugeescitizenship/news/notices/supplementary-immigration-levels-2018.html

Immigration, Refugees and Citizenship Canada. (2017f, Dec 31). Canada - Study permit holders on December 31st by province/territory of intended destination and study level. Temporary residents: Study permit holders - monthly IRCC updates. Retrieved December 31, 2017 from https://open.canada.ca/data/dataset/90115b00-f9b8-49e8-afa3-b4cff8facaee.

Immigration, Refugees and Citizenship Canada. (2018a). Express entry year-end report 2017 (p. 44). https://www.canada.ca/en/immigration-refugeescitizenship/corporate/publications-manuals/express-entry-year-end-report2017.html

Immigration, Refugees and Citizenship Canada. (2018b, February 20). How to immigrate-Atlantic Immigration Pilot. Retrieved July 17, 2018, from https://www.canada.ca/en/immigration-refugees-

citizenship/services/immigrate-canada/atlantic-immigration-pilot/how-toimmigrate.html\#sec1

Immigration, Refugees and Citizenship Canada. (2018c, May 11). 2018 Settlement program terms and conditions. https://www.canada.ca/content/dam/ircc/migration/ircc/english/transparency/do cuments/pdf/settlementprogram-en.pdf

Immigration, Refugees and Citizenship Canada. (2019a). Express entry year-end report 2019 (p. 38). https://www.canada.ca/en/immigration-refugeescitizenship/corporate/publications-manuals/express-entry-year-end-report2018.html

Immigration, Refugees and Citizenship Canada. (2019b, May 31). CanadaAdmissions of permanent residents with prior study permit holder status by province/territory of intended destination and immigration category. Transition from Temporary Resident to Permanent Resident Status - Quarterly IRCC Updates. Retrieved May 31, 2019 from https:/www.canada.ca/en/immigrationrefugees-citizenship/corporate/reports-statistics/statistics-open-data.html

Immigration, Refugees and Citizenship Canada. (2019c, May 31). CanadaAdmissions of permanent residents with prior International Mobility Program (IMP) work permit holder status under post-graduate employment by province/territory of intended destination and immigration category. Transition from Temporary Resident to Permanent Resident Status - Quarterly IRCC Updates. Retrieved May 31, 2019 from https://www.canada.ca/en/immigrationrefugees-citizenship/corporate/reports-statistics/statistics-open-data.html

Immigration, Refugees and Citizenship Canada. (2019d, May 31). CanadaAdmissions of permanent residents with prior International Mobility Program work permit holder status (for work purpose only) by provincelterritory of 
intended destination and immigration category. Transition from Temporary Resident to Permanent Resident Status - Quarterly IRCC Updates. Retrieved May 31, 2019 from https://www.canada.ca/en/immigration-refugeescitizenship/corporate/reports-statistics/statistics-open-data.html

Immigration, Refugees and Citizenship Canada. (2019e, May 31). CanadaAdmissions of permanent residents with prior Temporary Foreign Worker Program work permit holder status (for work purpose only) by provincelterritory of intended destination and immigration category. Transition from Temporary Resident to Permanent Resident Status - Quarterly IRCC Updates. Retrieved May 31, 2019 from https://www.canada.ca/en/immigration-refugeescitizenship/corporate/reports-statistics/statistics-open-data.html

Johnstone, M., \& Lee, E. (2014). Branded: International education and 21st-century Canadian immigration, education policy, and the welfare state. International Social Work, 57(3), 209-221.

$\mathrm{Lu}, \mathrm{Y} .$, \& Hou, F. (2015). International students who become permanent residents in Canada (No. 75-006-X) (p. 10). Statistics Canada.

Maclean's. (2017, November 1). The year's best. Maclean's Magazine, 130(10).

Ministère de l'Immigration, de la Diversité et de l'Inclusion. (2016). Plan d'immigration du Québec: pour l'année 2017. Gouvernement du Québec [ Quebec immigration plan: for the year 2017. Government of Quebec. http://www.midi.gouv.qc.ca/publications/fr/planification/Plan-immigration2017.pdf

Mosneaga, A. (2015). Managing international student migration: The practices of institutional actors in Denmark. International Migration, 53(1), 14-28.

Ontario Citizenship and Immigration. (2018, May 4). Ontario Immigrant Nominee Program (OINP): Monthly nomination and processing times reports. Retrieved June 1, 2018, from http://www.ontarioimmigration.ca/en/pnp/OI_PNP_PROCESSINGTIMES.htm 1

Roslyn Kunin \& Associates, Inc. (2009). Economic impact of international education in Canada (p. 63).

Roslyn Kunin \& Associates, Inc. (2012). Economic impact of international education in Canada-An update. (p. 65).

Roslyn Kunin \& Associates, Inc. (2016). Economic impact of international education in Canada-An update. (p. 82).

Standing Committee on Citizenship and Immigration. (2017). Immigration to Atlantic Canada: Moving to the future (p. 102). The House of Commons.

Statistics Canada. (n.d.). Table 37-10-0018-01 (CANSIM 477-0019). Postsecondary enrolments, by registration status, institution type, sex and student status. Retrieved from https://www150.statcan.gc.ca/t1/tbl1/en/tv.action?pid=3710001801

Trilokekar, R. D., \& El Masri, A. (2016). Canada's international education strategy: Implications of a new policy landscape for synergy between government policy and institutional strategy. Higher Education Policy, 29, 539-563.

Universities Canada. (2016). Enrolment by university. Retrieved July 27, 2017, from https://www.univcan.ca/universities/facts-and-stats/enrolment-by-university/ 
Walton-Roberts, M. W. (2011). Immigration, the university, and the welcoming second tier city. Journal of International Migration and Integration, 12(4), 453473.

ALEXANDRA M. BOZHEVA, PhD, Geography and Migration and Ethnic Relations, is a postdoctoral fellow with the Network for Economic and Social Trends (NEST) at Western University, Canada. Her major research interests are migration policy, higher education internationalization and international student migration, immigration geography, and retention rates. Email: abozheva@gmail.com 